University of Nebraska - Lincoln

DigitalCommons@University of Nebraska - Lincoln

Great Plains Wildlife Damage Control Workshop Wildlife Damage Management, Internet Center Proceedings

4-15-1991

\title{
EFFECTS OF A VISUAL BARRIER FENCE ON THE BEHAVIOR AND MOVEMENTS OF BLACK-TAILED PRAIRIE DOGS
}

Nancy S. Foster-McDonald

University of Nebraska, Lincoln

Scott E. Hygnstrom

University of Nebraska-Lincoln, shygnstrom1@unl.edu

Follow this and additional works at: https://digitalcommons.unl.edu/gpwdcwp

Part of the Environmental Health and Protection Commons

Foster-McDonald, Nancy S. and Hygnstrom, Scott E., "EFFECTS OF A VISUAL BARRIER FENCE ON THE BEHAVIOR AND MOVEMENTS OF BLACK-TAILED PRAIRIE DOGS" (1991). Great Plains Wildlife Damage Control Workshop Proceedings. 20.

https://digitalcommons.unl.edu/gpwdcwp/20

This Article is brought to you for free and open access by the Wildlife Damage Management, Internet Center for at DigitalCommons@University of Nebraska - Lincoln. It has been accepted for inclusion in Great Plains Wildlife Damage Control Workshop Proceedings by an authorized administrator of DigitalCommons@University of Nebraska - Lincoln. 


\section{EFFECTS OF A VISUAL BARRIER FENCE ON THE BEHAVIOR AND MOVEMENTS OF BLACK-TAILED PRAIRIE DOGS}

NANCY S. FOSTER-MCDONALD, Department of Forestry, Fisheries and Wildlife, University of Nebraska, Lincoln, NE 68583-0819

SCOTT E. HYGNSTROM, Department of Forestry, Fisheries and Wildlife, University of Nebraska, Lincoln, NE 68583-0819

Proceedings 10th Great Plains Wildlife Damage Conference (S.E. Hygnstrom, R.M. Case, and R.J. Johnson, eds.) Published at the University of Nebraska-Lincoln, 1991.

Abstract: Prairie dogs prefer an open view of their surroundings and may abandon an area with visual obstructions. We examined the effects of a visual barrier fence, which had a see-through visibility of $60 \%$, on the foraging, vigilance, and aggressive behaviors of adult female black-tailed prairie dogs (Cynomys ludovicianus) in central Nebraska. We expected animals near a visual barrier to spend more time in vigilance and less time foraging. Adult female prairie dogs exposed to a visual barrier spent a greater amount of time foraging and less time in a headbob position than those not exposed to a fence ( $P$ $=0.087, P=0.015)$. We also examined changes in prairie dog home ranges and use of an area in response to these visual barrier fences, expecting that prairie dogs would move away from fences over a 54-day period. If they invaded other territories, we expected to see more aggression on colonies with a fence. The size, shape, and location of home ranges and core activity areas of adult females did not change over time as a result of the presence of a visual barrier fence. We observed only 1 act of aggression during the study period. This apparent lack of aggression is likely due to the fidelity of study animals to established home ranges. The number of prairie dogs using areas at various distances from a visual barrier fence also did not change over this time $(P>$ $0.90)$. These results indicate that the visual barrier fence tested did not cause prairie dogs to be more vigilant and aggressive, nor did it affect their pre-established spatial use within the colony. 